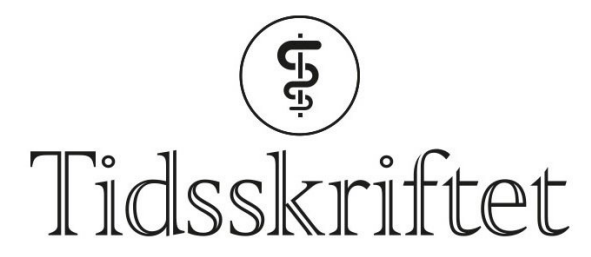

DEN NORSKE LEGEFORENING

\title{
Medisiner like bra som stent ved stabil angina
}

FRA ANDRE TIDSSKRIFTER

ØYVIND STOPLE SIVERTSEN

Tidsskriftet

Perkutan koronar intervensjonsbehandling gir ingen tilleggsgevinst ved optimalisert medikamentell behandling av stabil angina, ifølge en ny studie.

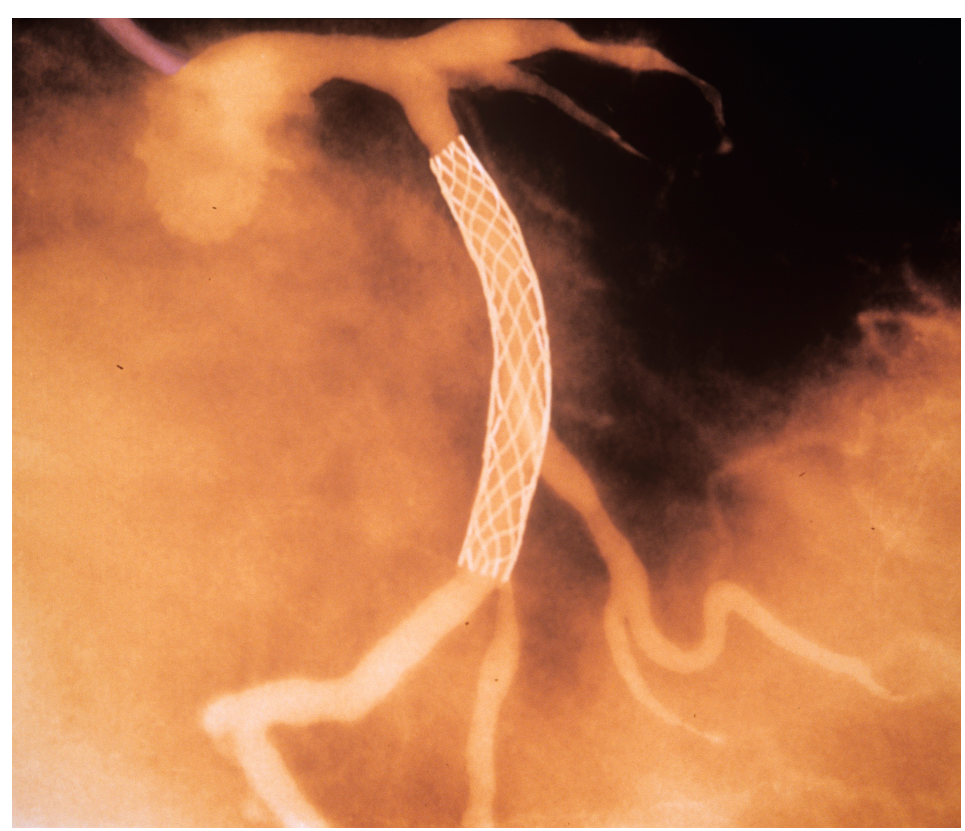

Farget angiogram av et snitt gjennom et hjerte som viser en stent implantert $i$ en kranspulsåre for å behandle stenose (innsnevring). Illustrasjonsfoto: Science Photo Library/NTB scanpix

I en studie, som nylig ble publisert i The Lancet, ble rundt 200 pasienter med stabil angina pectoris og minst 70 \% stenose i ett koronarkar fulgt opp av kardiolog med 1-3 konsultasjoner i løpet av seks uker, der den medikamentelle behandlingen ble optimalisert (1). Pasientene ble så randomisert til enten perkutan koronar intervensjonsbehandling (PCI) med innsettelse av stent eller til narrebehandling uten innsetting av stent.

Pasientenes fysiske yteevne ble målt med standardiserte tester før behandlingen og seks uker etter. De som hadde fått PCI-behandling, holdt ut 28,4 sekunder lenger enn før behandling, mens de som ikke fikk innsatt stent, holdt ut i 11,8 sekunder lenger. Forskjellen mellom gruppene var imidlertid ikke statistisk signifikant. Selv om behandlingen ikke hadde effekt på symptomene, reduserte intervensjonsbehandlingen iskemi. Dette ble vist 
ved stressekkokardiografi og intrakoronar trykkmåling.

- Dette er en interessant studie, og resultatene kommer helt sikkert til å bli diskutert i mange fora i tiden som kommer, sier Svein Rotevatn, overlege ved Hjerteavdelingen, Haukeland universitetssykehus.

- Noen forhold ved studien begrenser betydningen av funnene. For det første var det få pasienter i studien, og oppfølgingstiden var kort, bare seks uker. For det andre viste intrakoronare trykkmålinger før intervensjonen at det ikke var tegn til iskemi hos ca. 30 \% av pasientene, og slike pasienter skal etter gjeldende retningslinjer og vanlig praksis ikke få slik behandling. For det tredje viste livskvalitetsundersøkelsene at pasientene før intervensjon hadde få anginaanfall, anslagsvis kun én gang i måneden, sier Rotevatn.

LITTERATUR:

1. Al-Lamee R, Thompson D, Dehbi HM et al. Percutaneous coronary intervention in stable angina (ORBITA): a double-blind, randomised controlled trial. Lancet 2018; 391:31 - 40. [PubMed][CrossRef]

Publisert: 5. mars 2018. Tidsskr Nor Legeforen. DOI:10.4045/tidsskr.18.0032

(C) Tidsskrift for Den norske legeforening 2020. Lastet ned fra tidsskriftet.no 